\title{
Aberrant non-neoplastic liver tissue presenting as an intra-atrial mass
}

\author{
Benjamin Peake, ${ }^{1}$ Siven Seevanayagam, ${ }^{2}$ Melisa Vazquez, ${ }^{3}$ Laurence Weinberg $^{1,4}$
}

${ }^{1}$ Department of Anaesthesia, Austin Hospital, Heidelberg, Victoria, Australia

${ }^{2}$ Department of Cardiac Surgery, Austin Health, Heidelberg, Victoria, Australia ${ }^{3}$ Department of Anatomical Pathology, Austin Hospital, Heidelberg, Victoria, Australia ${ }^{4}$ Surgery and Anaesthesia Perioperative Pain Medicine Unit, University of Melbourne, Melbourne, Victoria, Australia

\section{Correspondence to} A/Professor Laurence

Weinberg, laurence.weinberg@ austin.org.au

Accepted 6 March 2017

\section{DESCRIPTION}

A Caucasian woman aged 66 years underwent transthoracic echocardiography prior to initiation of clozapine treatment for schizophrenia. Echocardiography demonstrated a mobile $25 \times 20 \times 15 \mathrm{~mm}$ mass arising from the posterior right atrial wall adjacent to the Eustachian valve. There was no obstruction of the inferior vena cava (IVC), coronary sinus or tricuspid valve. Routine haematology and biochemistry, including liver function and cardiac enzymes, were within normal limits. Physical examination and ECG were unremarkable. Sine sequence cardiac MRI confirmed a low signal mobile right atrial mass (diameter $21 \times 22 \mathrm{~mm}$ ), appearances and tissue characterisation of which were suggestive of a benign atrial myxoma (figure $1 \mathrm{~A}$ ). The MRI suggested the mobile mass was attached to the Eustachian valve by a thin stalk. Intraoperative transoesophageal echocardiography revealed a noncalcified homogenous broad-based mass adjacent to the IVC-right atrium junction (figure 2A). Right atriotomy confirmed the lesion originated from the middle hepatic vein/IVC junction. Surgical excision was performed under hypothermic cardiopulmonary bypass and total circulatory arrest. A bovine pericardial patch reconstruction of the IVC-hepatic veins confluence and reconstruction of left and middle hepatic veins was successfully undertaken. Histology revealed a $4.8 \mathrm{~g}, 28 \times 24 \times 14 \mathrm{~mm}$ lobulated mass of aberrant non-neoplastic liver tissue present within the lumen of the vein (figure 2B). CD34 endothelial staining and smooth muscle actin tunica media staining were positive. Post hoc review of the cardiac MRI suggested (figure 1B) the tissue characteristics of the intra-atrial mass to be of the same consistency as the liver parenchyma. The patient achieved full neurological recovery and was discharged 2 weeks postoperatively.

Only two cases of a similar pathology have previously been described. ${ }^{1}{ }^{2}$ Based on the embryologic intimacy between the caudate lobe and the IVC, it is possible that the intra-atrial benign liver tissue
CrossMark

\section{To cite: Peake $B$,}

Seevanayagam $S$

Vazquez M, et al. BMJ Case Rep Published online:

[please include Day Month

Year] doi:10.1136/bcr-2017219463
A

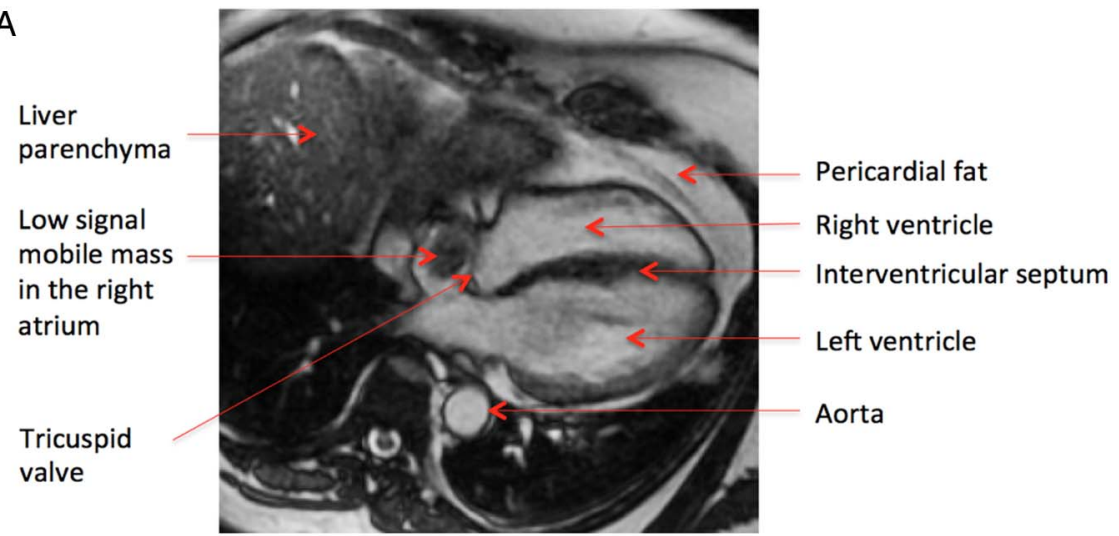

B

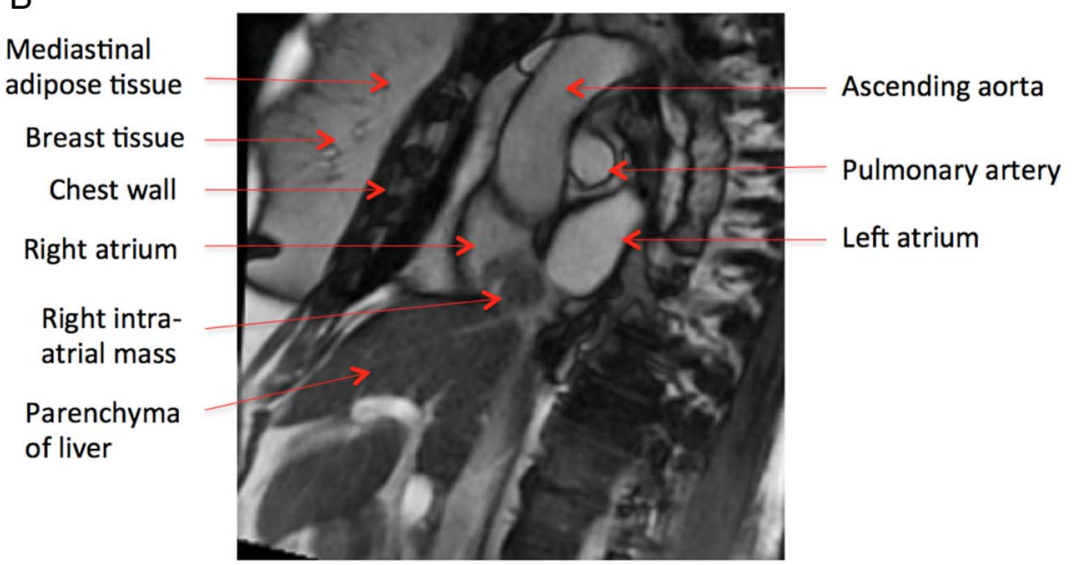

Figure 1 (A) Axial plane cardiac sine MRI with true fast imaging with steady-state precession demonstrates a low signal mobile mass in the right atrium. (B) Sagittal plane cardiac MRI demonstrates a right atrial mass with identical imaging characteristics to the liver parenchyma. 

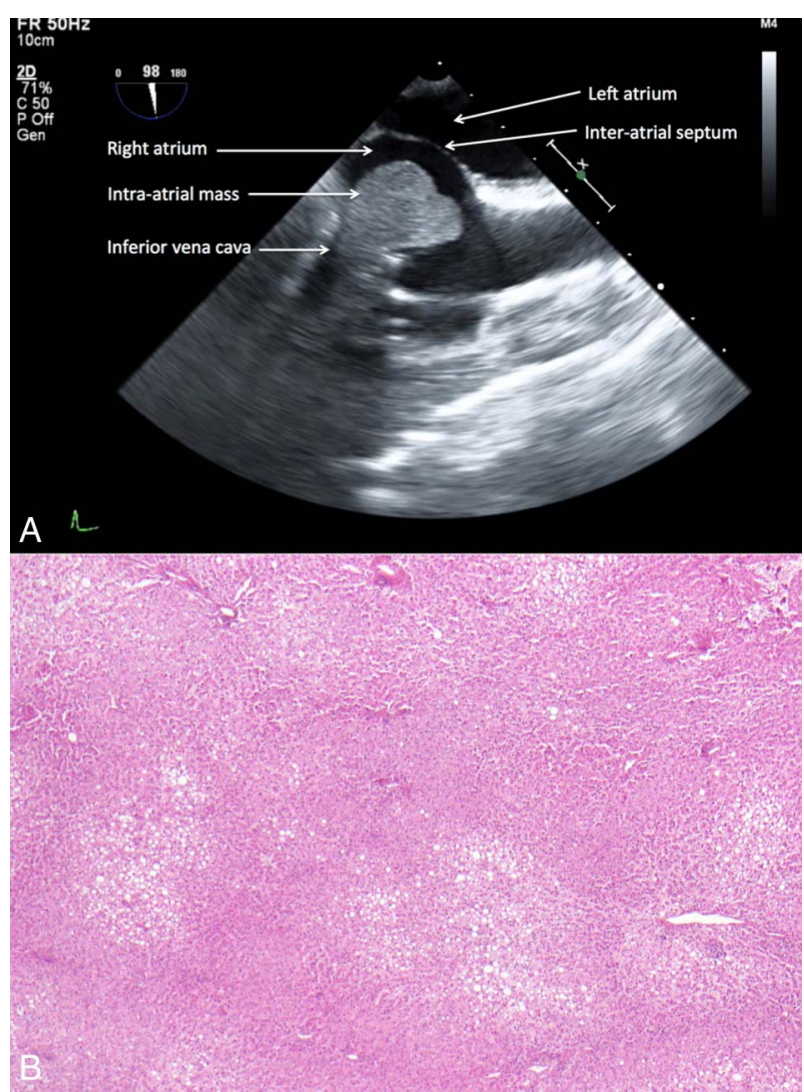

Figure 2 (A) Intraoperative transoesophageal echocardiography demonstrates a broad-based aberrant non-neoplastic liver mass in the right atrium. (B) Non-neoplastic liver tissue (stained with H\&E) with preserved lobular architecture and steatosis (×100 magnification).

was due to aberrant migration of hepatocytes into the IVC during embryogenesis. ${ }^{1}$ Aberrant liver tissue as an intra-atrial mass is usually asymptomatic. Accurate diagnosis and surgical resection is important to prevent complications such as obstruction coronary sinus or tricuspid valve, interference with circulation and embolisation. Although benign aberrant intra-atrial liver tissue is very rare, it should be considered in patients with no known malignancy and where imaging characteristics of thrombus are absent.

\section{Learning points}

- Aberrant non-neoplastic liver tissue is rare and can present as an intra-atrial mass.

- It has been postulated that benign intra-atrial liver tissue is due to aberrant migration of hepatocytes into the inferior vena cava during embryogenesis.

- Surgical resection should be considered to prevent complications such as obstruction of the circulation, interference with heart valves and embolisation.

Contributors LW was the principal anaesthetist involved in management of this case and performed the transoesophageal echocardiography examinations. He was responsible for collation of all clinical images, interpretation of all data and the writing of the report. BP was responsible for the literature review, collation of all clinical images and for the writing of the report. MV was responsible for the collation of all anatomical images and for the writing of the report. SS was the principal cardiac surgeon involved in managing the case and was responsible for collation of all clinical images and for the writing of the report.

Competing interests None declared.

Patient consent Obtained.

Provenance and peer review Not commissioned; externally peer reviewed.

\section{REFERENCES}

1 Chapman-Fredricks J, Birusingh R, Ricci M, et al. Intracaval liver with cardiac extension. A new developmental anomaly? Fetal Pediatr Pathol 2010;29:401-6.

2 Ansari-Gilani $K$, Jenkins $T$, Landeras $L$, et al. Multimodality imaging of an unusual case of an obstructive intracaval mass by an aberrant liver. Circulation 2014;129: e310-12.

Copyright 2017 BMJ Publishing Group. All rights reserved. For permission to reuse any of this content visit

http://group.bmj.com/group/rights-licensing/permissions.

BMJ Case Report Fellows may re-use this article for personal use and teaching without any further permission.

Become a Fellow of BMJ Case Reports today and you can:

- Submit as many cases as you like

- Enjoy fast sympathetic peer review and rapid publication of accepted articles

- Access all the published articles

- Re-use any of the published material for personal use and teaching without further permission

For information on Institutional Fellowships contact consortiasales@bmjgroup.com

Visit casereports.bmj.com for more articles like this and to become a Fellow 